\title{
HEAVY METALS IN TRIBUTARIES OF PAMPULHA RESERVOIR, MINAS GERAIS
}

\author{
RIETZLER, A. C., ${ }^{1}$ FONSECA, A. L. ${ }^{2}$ and LOPES, G. P. ${ }^{3}$ \\ ${ }^{1}$ Departamento de Biologia Geral, ICB, UFMG, Belo Horizonte, MG \\ ${ }^{2}$ EFEI, Instituto de Engenharia Mecânica de Itajubá, MG \\ ${ }^{3}$ Centro de Recursos Hídricos e Ecologia Aplicada, EESC, USP, São Carlos, SP \\ Correspondence to: Arnola C. Rietzler, Departamento de Biologia Geral, Universidade Federal de \\ Minas Gerais, Av. Antônio Carlos, 6627, CEP 31270-901, Belo Horizonte, MG, Brazil, \\ e-mail: rietzler@mono.icb.ufmg.br \\ Received April 18, 2000 - Accepted August 25, 2001 - Distributed August 31, 2001
}

(With 2 figures)

\begin{abstract}
A great amount of heavy metals enter Pampulha Reservoir via it's main tributaries (Sarandi and Ressaca). Although no water quality classification has been carried out for these tributaries, the reservoir is expected to be in class 2 of the CONAMA-86 system. As part of a monitoring scheme of the Pampulha Watershed, heavy metals $(\mathrm{Zn}, \mathrm{Pb}, \mathrm{Cd}, \mathrm{Ni}, \mathrm{Cu}, \mathrm{Cr}, \mathrm{Mn}$ and $\mathrm{Fe}$ ) were investigated in the water at a control site (considered free from direct human influence) and at potential sites of toxicity and contamination during August (dry season) and November (wet season) of 1998. The results for the first sampling period showed relatively high concentrations of zinc $\left(0.22 \mathrm{mg} . \mathrm{L}^{-1}\right)$ in the upper portion of the reservoir. The highest values of nickel and chromium ( 0.19 and $0.89 \mathrm{mg} . \mathrm{L}^{-1}$, respectively) were found in the initial portion of the Sarandi Stream, while the highest concentrations of lead $\left(0.05 \mathrm{mg} . \mathrm{L}^{-1}\right)$, cadmium $\left(0.014 \mathrm{mg} . \mathrm{L}^{-1}\right)$, manganese $(0.43$ $\left.\mathrm{mg} . \mathrm{L}^{-1}\right)$ and iron $\left(15.25 \mathrm{mg} . \mathrm{L}^{-1}\right)$ were detected in the Ressaca Stream by the landfill dump of Belo Horizonte. A relatively high concentration of cadmium was also detected at the confluence of the two streams. During the second sampling period, there was an increase in the concentrations of zinc at all sampling sites except the control, with values varying from $0.71 \mathrm{mg} . \mathrm{L}^{-1}$ (the Sarandi Stream) to $2.50 \mathrm{mg} . \mathrm{L}^{-1}$ (the Ressaca Stream). Lead, cadmium, nickel and chromium concentrations were also higher in the Ressaca Stream, but not detected at the other sampling sites. Copper values were higher than in the first period: $0.10 \mathrm{mg} . \mathrm{L}^{-1}$ at the control up to $0.38 \mathrm{mg} . \mathrm{L}^{-1}$ at the confluence of the streams. Similar results were found for manganese and iron, with values reaching up to 19.30 and $125 \mathrm{mg} . \mathrm{L}^{-1}$, respectively. Moreover, all values recorded in the second sampling period were much higher than recommended for class 2 waters. These results emphasize the need for such monitoring in relation to better water quality management of this reservoir.
\end{abstract}

Key words: heavy metals, monitoring, Pampulha Watershed, water quality.

\section{RESUMO}

Metais pesados em tributários da represa da Pampulha, Minas Gerais

Os efluentes lançados nos principais tributários da represa da Pampulha (Sarandi e Ressaca) estão em grande parte representados por metais pesados. Embora não haja enquadramento para a qualidade da água destes tributários, por apresentarem trechos canalizados, os limites recomendados para o reservatório o classificam como classe 2. Dentre os aspectos ecotoxicológicos considerados no monitoramento da Bacia da Pampulha, foram investigados teores de metais pesados ( $\mathrm{Zn}, \mathrm{Pb}, \mathrm{Cd}, \mathrm{Ni}, \mathrm{Cu}, \mathrm{Cr}, \mathrm{Fe}$ e $\mathrm{Mn}$ ) na água, em locais com potencial de toxicidade e contaminação, durante agosto (estação seca) e novembro/98 (estação chuvosa). Os primeiros resultados mostraram concentrações relativamente elevadas de zinco $\left(0,22 \mathrm{mg} . \mathrm{L}^{-1}\right)$ na porção inicial do reservatório. No início do Córrego Sarandi, foram encontrados os maiores teores de níquel e cromo $(0,19$ e 0,89 mg. $\mathrm{L}^{-1}$, respectivamente), enquanto as maiores concentrações de chumbo $\left(0,05 \mathrm{mg} . \mathrm{L}^{-1}\right)$, cádmio $(0,014$ mg. $\left.\mathrm{L}^{-1}\right)$, manganês $\left(0,43 \mathrm{mg} . \mathrm{L}^{-1}\right)$ e ferro $\left(15,25 \mathrm{mg} . \mathrm{L}^{-1}\right)$ foram encontradas no Córrego Ressaca, onde está situado o aterro sanitário de Belo Horizonte. Uma concentração relativamente elevada de cádmio também foi verificada 
na junção dos córregos Sarandi e Ressaca. No segundo período de análises, verificou-se um aumento nas concentrações de zinco em todos os pontos de amostragem, exceto no controle, com valores entre 0,71 (Córrego Sarandi) e 2,50 mg.L L $^{-1}$ (Córrego Ressaca). Chumbo, cádmio, níquel e cromo apresentaramse em maiores concentrações no Córrego Ressaca, não tendo sido detectados nos demais pontos de amostragem. Os valores de cobre foram mais elevados que os obtidos em agosto/98, entre 0,10 (controle) e $0,38 \mathrm{mg} \cdot \mathrm{L}^{-1}$ (junção). O mesmo foi verificado em relação ao manganês e ao ferro, cujos valores chegaram a 19,3 e 125,0 mg.L $\mathrm{L}^{-1}$, respectivamente. Além disso, todos os valores de metais detectados no segundo período de amostragem estiveram muito acima dos valores recomendados para águas classe 2 . Os resultados mostram a necessidade de continuidade do monitoramento desses metais, devido ao interesse na melhoria da qualidade da água do reservatório.

Palavras-chave: metais pesados, monitoramento, Bacia da Pampulha, qualidade da água.

\section{INTRODUCTION}

Heavy metals may enter aquatic ecosystems through natural processes such as soil leaching, rock erosion, and volcanic activity. In addition, numerous sources, at times difficult to identify, originate from industrial activity, as well as from domestic effluents, and sludge from treatment plants (Jackson, 1992).

The Pampulha watershed is of importance for the city of Belo Horizonte, representing a large green area suitable for leisure activities. Surface area is $97 \mathrm{~km}^{2}$. Within this watershed, the reservoir of Pampulha was constructed in 1938, and reconstructed in 1957; this waterbody has a surface area of approximately $2.4 \mathrm{~km}^{2}$ and a maximum depth of 16 metres (Pinto-Coelho, 1997). Initially a tourist attraction and recreational area, it was also used as a source of water for various parts of the city until the last decade, at which time, problems with the quality of the water became evident (PintoCoelho, 1992; Giani, 1994). At present, the main tributaries which comprise the watershed (namely the Sarandi and Ressaca streams) receive effluents from industries of the area, domestic effluents, solid wastes, wastes from flood run-off, and liquid wastes from land-fill dumps. These wastes include considerable quantities of heavy metals, which directly affect the water quality and aquatic biota of the reservoir (Champs, 1992; Pinto-Coelho \& Greco, 1998).

Barbosa et al. (1998) carried out a mass balance analysis of the reservoir for nitrogen and phosphorus, considering estimations of the quantities of these elements entering, leaving and being retained within the water body. A high level of eutrophication was recorded, with greatest loads of $\mathrm{N}$ and $\mathrm{P}$ being supplied by the Sarandi and Ressaca streams.
Pinto-Coelho (1997) has monitored the reservoir since 1984, with particular emphasis on limnological aspects, generating a database on the water quality deterioration over the last 15 years. According to the latter author, this deterioration has led to the disappearance of some zooplankton taxa, including Scolodiaptomus corderoi and Bosmina sp. which were abundant in the last decade, but not recorded since 1994 .

In view of these environmental problems, the Municipal Prefectures of Belo Horizonte and Contagem, in conjunction with Copasa (the Sanitation Company of Minas Gerais) and Feam (State Foundation of the Environment), elaborated programmes of sanitation and recuperation for the water-shed. Included in these measures were the removal and treatment of industrial and domestic effluents, and prevention of the addition of untreated effluents to the tributaries of the reservoir.

In this context, as part of a project on monitoring the quality of the water and sediments of the watershed, with the aim of providing information on ecotoxicological aspects for management and recuperation planning of the reservoir, the present study was carried out to determine the concentrations of the metals zinc, lead, cadmium, nickel, copper, chromium, iron, and manganese at various locations in the watershed. Of particular interest was how such concentrations would compare to the limits established for class 2 waters of the CONAMA-86 system; the Sarandi and Ressaca streams have been considered to belong to this class.

\section{MATERIAL AND METHODS}

The location of the sampling points are shown in Fig. 1. Water samples were collected in August (dry season) and November (wet season) of 1998. 
Lead, zinc, nickel, cadmium, copper, iron, manganese and chromium concentrations were determined following the methodology described in APHA (1995), with concentrated nitric acid digestion. Water samples of one litre in volume were taken at each sampling point, with $5 \mathrm{ml}$ of $\mathrm{HNO}_{3}$ being added to each. Digestion was carried out in a fume cupboard to give a final volume of 20-30 ml. These samples were stored for subsequent analysis using atomic absorption spectrometry.

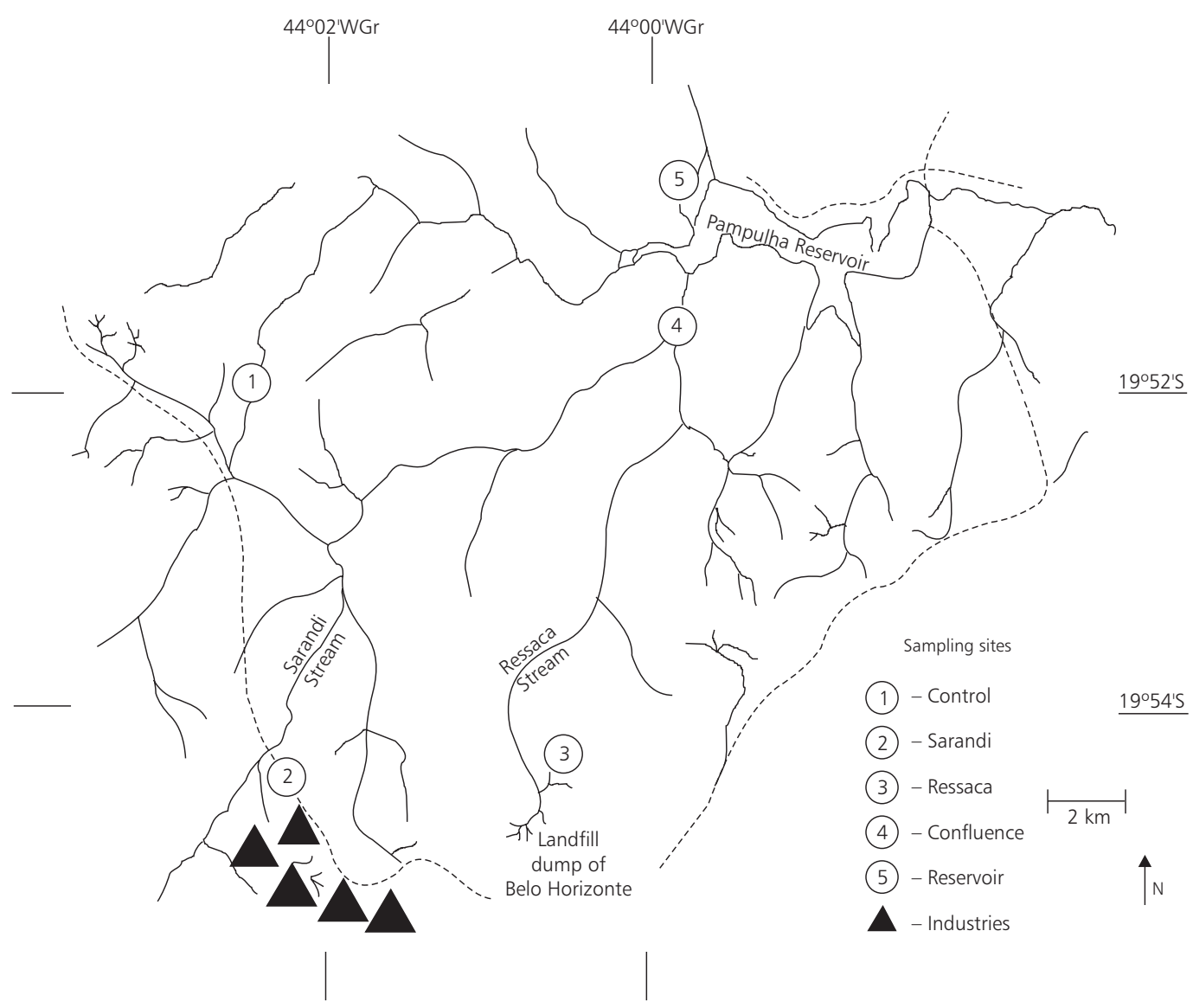

Fig. 1 - Location of sampling points in the Pampulha Watershed.

\section{RESULTS}

Zinc concentrations varied between 0.00048 and $0.22 \mathrm{mg} . \mathrm{L}^{-1}$ in the dry season, and 0.71 and 2.50 mg. $\mathrm{L}^{-1}$ in the wet season (Fig. 2a). Considering the limit established by CONAMA-86 for Class 2 waters, the concentrations found during the wet season exceed the permissible limit for all sampling points, especially in the Ressaca Stream, where the value was 13.8 times greater than this limit (Table 1). The values obtained for lead and cadmium are shown in Figs. 2b and c, respectively. For both metals, values varied from below the limit of analytical detection (0.002 and $0.0006 \mathrm{mg} . \mathrm{L}^{-1}$, respectively), to above the permissible limits.

The Ressaca Stream showed values above the permissible during both dry and wet seasons, being 0.05 to $0.82 \mathrm{mg} . \mathrm{L}^{-1}$ for lead, and 0.014 and $0.18 \mathrm{mg} . \mathrm{L}^{-1}$ for cadmium. During the wet season, values were extremely high, surpassing the limit by a magnitude of 27.5 times for lead and 180 times for cadmium (Table 1). 

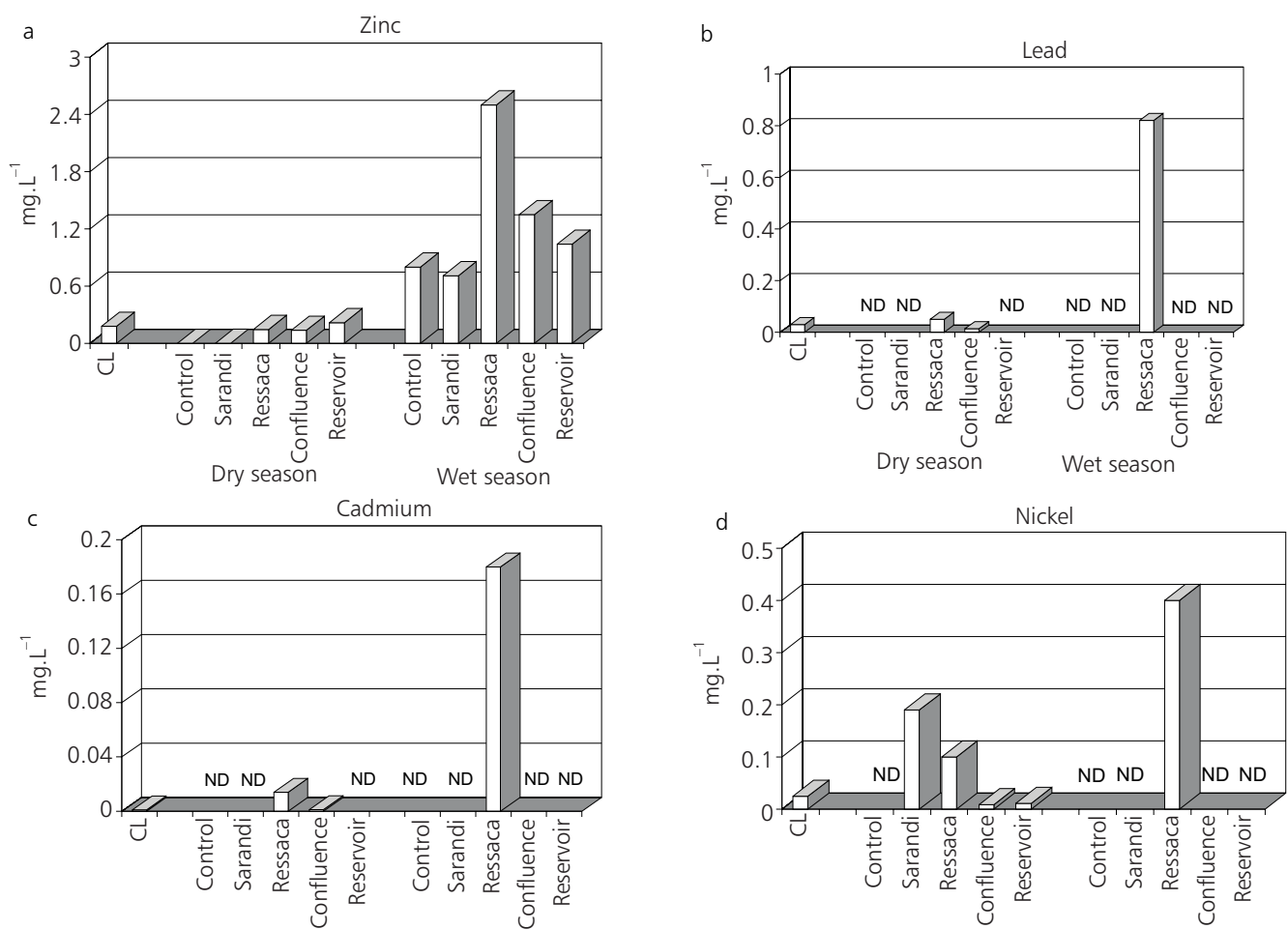

Dry season

Wet season

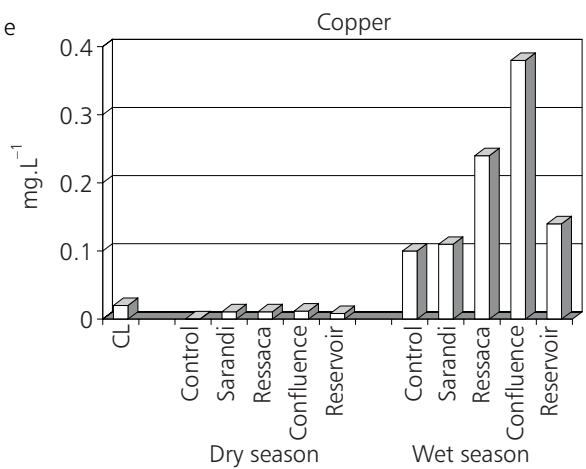

Dry season

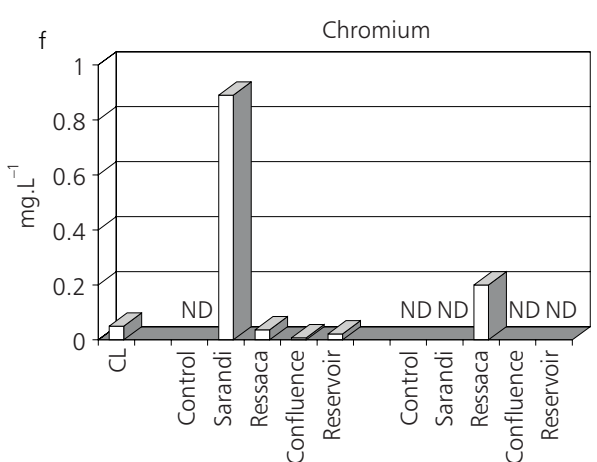

g
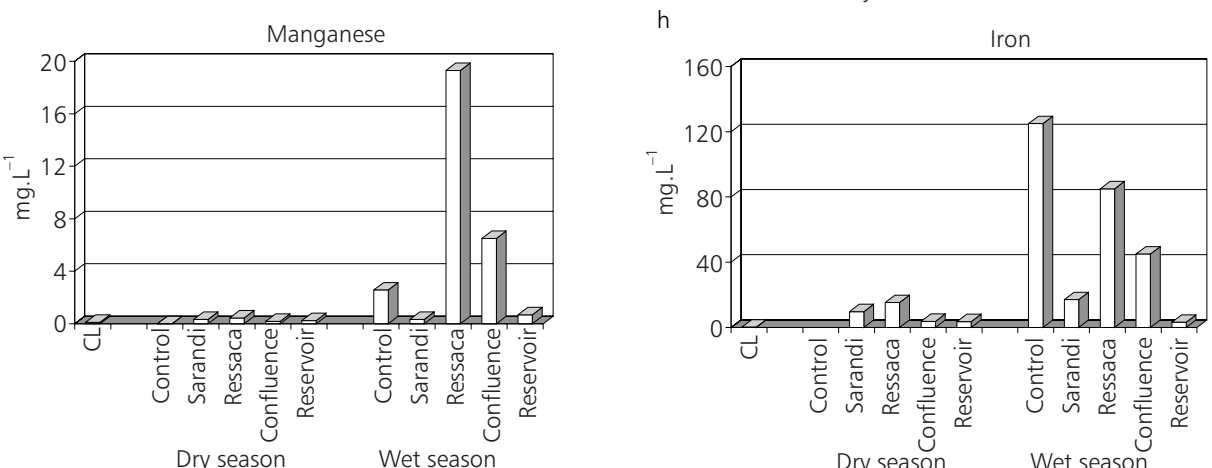

$\mathrm{CL}$ indicates concentration limits for class 2 waters and ND indicates values below the limits of detection by spectrophotometry, such limits (in mg. $\mathrm{L}^{-1}$ ) being $0.002(\mathrm{~Pb}) ; 0.0006(\mathrm{Cd}) ; 0.008(\mathrm{Ni})$; and $0.005(\mathrm{Cr})$.

Fig. 2 - Heavy metal concentrations in the water samples collected in August (dry season) and November (wet season) of 1998, in the Pampulha Watershed. 
Nickel concentrations varied between 0.0082 and $0.40 \mathrm{mg} . \mathrm{L}^{-1}$, considering both sampling periods. Fig. $2 \mathrm{~d}$ shows that, during the dry season, the highest values were found in the Sarandi and Ressaca streams, while during the wet season, the highest values were found in the Ressaca Stream (Table 1), surpassing during both seasons, the legal limit.
Highest copper concentrations were found during the second sampling period, varying between 0.00048 and $0.012 \mathrm{mg} . \mathrm{L}^{-1}$ in the dry season, and 0.10 and $0.38 \mathrm{mg} . \mathrm{L}^{-1}$ in the wet (Fig. 2e). During the wet season, such values were greater than that permitted for class 2 waters, at all sampling locations (Table 1).

TABLE 1

Number of occasions that the concentration limit for class 2 waters were surpassed, at the five sampling points in Pampulha Watershed.

\begin{tabular}{|c|c|c|c|}
\hline Metal & Sampling points & Dry season & Wet season \\
\hline Zinc & $\begin{array}{l}\text { Control } \\
\text { Sarandi } \\
\text { Ressaca } \\
\text { Confluence Sarandi/Ressaca } \\
\text { Reservoir } \\
\end{array}$ & $\begin{array}{l}- \\
- \\
- \\
- \\
1.2 \\
\end{array}$ & $\begin{array}{c}4.4 \\
3.9 \\
13.8 \\
7.5 \\
5.7 \\
\end{array}$ \\
\hline Lead & $\begin{array}{l}\text { Control } \\
\text { Sarandi } \\
\text { Ressaca } \\
\text { Confluence Sarandi/Ressaca } \\
\text { Reservoir } \\
\end{array}$ & $\begin{array}{l}- \\
- \\
0.7 \\
- \\
-\end{array}$ & $\begin{array}{c}- \\
- \\
27.5 \\
- \\
- \\
\end{array}$ \\
\hline Cadmium & $\begin{array}{l}\text { Control } \\
\text { Sarandi } \\
\text { Ressaca } \\
\text { Confluence Sarandi/Ressaca } \\
\text { Reservoir } \\
\end{array}$ & $\begin{array}{c} \\
- \\
14.0 \\
- \\
- \\
\end{array}$ & $\begin{array}{c}- \\
- \\
180.0 \\
- \\
- \\
\end{array}$ \\
\hline Nickel & $\begin{array}{l}\text { Control } \\
\text { Sarandi } \\
\text { Ressaca } \\
\text { Confluence Sarandi/Ressaca } \\
\text { Reservoir } \\
\end{array}$ & $\begin{array}{c}- \\
7.6 \\
4.0 \\
- \\
- \\
\end{array}$ & $\begin{array}{c}- \\
- \\
16.0 \\
- \\
- \\
\end{array}$ \\
\hline Copper & $\begin{array}{l}\text { Control } \\
\text { Sarandi } \\
\text { Ressaca } \\
\text { Confluence Sarandi/Ressaca } \\
\text { Reservoir } \\
\end{array}$ & $\begin{array}{l}- \\
- \\
- \\
-\end{array}$ & $\begin{array}{c}5.0 \\
5.5 \\
12.0 \\
19.0 \\
70 \\
\end{array}$ \\
\hline Chromium & $\begin{array}{l}\text { Control } \\
\text { Sarandi } \\
\text { Ressaca } \\
\text { Confluence Sarandi/Ressaca } \\
\text { Reservoir }\end{array}$ & $\begin{array}{c}- \\
17.8 \\
- \\
- \\
-\end{array}$ & $\begin{array}{l}- \\
- \\
4.0 \\
- \\
-\end{array}$ \\
\hline Manganese & $\begin{array}{l}\text { Control } \\
\text { Sarandi } \\
\text { Ressaca } \\
\text { Confluence Sarandi/Ressaca } \\
\text { Reservoir } \\
\end{array}$ & $\begin{array}{l}- \\
3.2 \\
4.3 \\
1.8 \\
2.3 \\
\end{array}$ & $\begin{array}{c}25.7 \\
3.3 \\
193.0 \\
65.0 \\
6.8 \\
\end{array}$ \\
\hline Iron & $\begin{array}{l}\text { Control } \\
\text { Sarandi } \\
\text { Ressaca } \\
\text { Confluence Sarandi/Ressaca } \\
\text { Reservoir }\end{array}$ & $\begin{array}{c}- \\
48.5 \\
76.2 \\
18.2 \\
17.5\end{array}$ & $\begin{array}{c}625.0 \\
8.5 \\
425.0 \\
225.0 \\
15.7\end{array}$ \\
\hline
\end{tabular}


Chromium concentrations varied between 0.0078 and $0.89 \mathrm{mg} . \mathrm{L}^{-1}$ in the dry season, and from below the detectable limit $\left(0.005 \mathrm{mg} . \mathrm{L}^{-1}\right)$ to 0.20 mg.L $L^{-1}$ in the wet season (Fig. 2f). Highest values were obtained in the Sarandi Stream during the dry season, and the Ressaca Stream during the wet (Table 1), surpassing the permitted level by magnitudes of 17.8 and 4 , respectively.

Manganese concentrations varied between 0.0024 and $0.43 \mathrm{mg} . \mathrm{L}^{-1}$ during the dry season, and 0.33 and 19.3 mg.L - $^{-1}$ during the wet (Fig. $2 \mathrm{~g}$ ). Highest concentrations were recorded during the wet season, principally in the Ressaca Stream, and at the confluence of the Sarandi and Ressaca (Table 1), surpassing the permissible limit by magnitudes of 193 and 65, respectively.

For iron, highest values were found during the wet season at all sampling points, with the exception of within the reservoir (Fig. 2h). Such values varied from below the detection limit to $15.2 \mathrm{mg} . \mathrm{L}^{-1}$ in the dry season, and from 3.15 to $125 \mathrm{mg} . \mathrm{L}^{-1}$ in the wet. The permissible limit was surpassed at all sampling locations in both seasons, with the exception of the Control location during the dry season (Table 1).

\section{DISCUSSION}

Among the environmental impacts of human activities are included changes in the biogeochemical cycling of trace metals, which enter the environment from liquid and solid effluents, and via the atmosphere, accumulating in depositing areas. Several of these metals may be considered as essential elements for living organisms, such as $\mathrm{Zn}, \mathrm{Co}$ and $\mathrm{Cu}$, only becoming toxic at elevated environmental concentrations. Others, such as $\mathrm{Pb}, \mathrm{Hg}$ and $\mathrm{Cd}$, are not used by organisms, although being chemically related to the essential metals, and are toxic at very low concentrations (Odum, 1985; Freedman, 1995).

The bioavailability of heavy metals in aquatic ecosystems is related to a wide variety of physical and chemical factors, such as the chemical form of the metal, the $\mathrm{pH}$ of the water, the presence of calcium and magnesium ions (expressed as water hardness), nutrient concentrations and the quantity and nature of material in suspension (Pain, 1995; Ripley et al., 1996). In general, such metals are less toxic in hard waters, as the toxicity is diminished by the formation of complexes with carbonate ions, and by competition with calcium ions (Wren et al., 1995).
Investigations on the toxicity of lead to aquatic organisms, carried out by the Environmental Protection Agency of the USA (USEPA, 1985), indicated an $\mathrm{LC}_{50}$ of $0.6 \mathrm{mg} . \mathrm{L}^{-1}$ of $\mathrm{Pb}$ for Daphnia magna in water with a hardness of $54 \mathrm{mg} . \mathrm{L}^{-1}$ of $\mathrm{CaCO}_{3}$ increasing to $1.9 \mathrm{mg} . \mathrm{L}^{-1}$ in water with a hardness of $152 \mathrm{mg} . \mathrm{L}^{-1}$ of $\mathrm{CaCO}_{3}$. A similar pattern was found for the fish Pimephales promelas, Salmo gairdneri, and Lepomis macrochirus (Pain, op. cit.). Similarly, Demayo et al. (1982) found that the toxicity for Daphnia magna of cadmium was between 0.034 and $0.060 \mathrm{mg} . \mathrm{L}^{-1}$ in moderately hard waters, and less in harder waters. The elevated concentrations of lead and cadmium found in the present study during the wet season at location 3 (the Sarandi Stream) (0.82 mg.L $\mathrm{L}^{-1}$ for lead, and 0.18 $\mathrm{mg} . \mathrm{L}^{-1}$ for cadmium), in combination with the moderate water hardness $\left(90 \mathrm{mg} . \mathrm{L}^{-1} \mathrm{CaCO}_{3}\right)$, would suggest a toxic effect for cladocerans if exposed to such waters.

Zinc is often encountered in the environment bound with sulphur, its bioaccumulation depending on the trophic level (Eysink et al., 1988). In an examination of heavy metal concentrations in zooplanktonic organisms and the macrophyte Eichhornia crassipes within Pampulha Reservoir, PintoCoelho \& Greco (1998), found that zinc was the metal with highest concentrations in the biomass (on average approximately $177 \mathrm{mg} . \mathrm{L}^{-1}$ for the zooplankton and $69 \mathrm{mg} . \mathrm{L}^{-1}$ for $E$. crassipes), such values being far greater than those found in the water. According to the authors, the position of the zooplankton in the second and third trophic levels permitted bioaccumulation of this element in their biomass.

The zinc concentrations found in the present study confirm the accumulative potential of this element for the aquatic biota, especially the values recorded during the wet season, when the limit permitted for class 2 waters $\left(0.05 \mathrm{mg} . \mathrm{L}^{-1}\right)$ was surpassed at all sampling locations (Table 1). The sampling location chosen as the control also had a concentration 1.2 times greater than the permissible level during the dry season, bringing into question whether this location can really be considered as a control.

Although copper is essential for chlorophyll synthesis, toxic concentrations occur in the environment as a result of mining, smelting, acid precipitation, and the use of this element in the form of 
oxide or sulphate as a pesticide, algicide, and fungicide (Laurén \& McDonald, 1986). According to Boldrini \& Pereira (1987), copper concentrations between 0.005 and $0.015 \mathrm{mg} . \mathrm{L}^{-1}$ do not cause deleterious effects on various aquatic organisms. However, the concentrations recorded in the present study, during the wet season, were all greater than the above quoted values.

The elevated concentrations of nickel found in the Sarandi and Ressaca streams during the dry season, and in the Ressaca Stream during the wet season, could also be causing negative effects on the biota.

Hexavalent chromium is highly mobile in aquatic environments, and is toxic for many organisms. On the other hand, $\mathrm{Cr}$ III is much less toxic, and is indeed essential in human and animal nutrition. This form tends to be associated with solid material, and is relatively immobile in the environment. The most important reducers found in natural systems are organic compounds and divalent iron. Iron acts as a redox catalyst, transforming $\mathrm{Cr}$ VI to $\mathrm{Cr}$ III in environments rich in organic matter (Burge \& Hug, 1998). According to the latter authors, Fe II is an important agent in the remediation of areas contaminated with $\mathrm{Cr}$ VI. In contrast, manganese hydroxides (III e IV), present in such areas, can act as reoxidizers, forming $\mathrm{Cr}$ VI.

The concentrations of iron found in the present study were far superior to those of manganese, during both sampling periods, at all sampling locations, except at the control location during the dry season. Considering the high concentrations of both $\mathrm{Fe}$ and $\mathrm{Mn}$ naturally found in this watershed, analysis of the species present of $\mathrm{Mn}, \mathrm{Fe}$ and $\mathrm{Cr}$, especially in the Sarandi and Ressaca streams, could help in designing remediation measures for the watershed.

River sediments are potential sources of contamination, including heavy metals, for aquatic ecosystems. During the last decade, much of the research on metal pollution in water has concentrated on controlling mechanisms for the mobility and bioavailability of different metal species, with regard to different size classes of particles, as in general, metal concentrations in sediments increase with decreases in particle size (Murray et al., 1999).
The majority of transported and sedimented material in the tributaries of the Pampulha Watershed consist of sand, reaching $73 \%$ at the confluence of the Sarandi and Ressaca streams (Rietzler et al., in prep.). Within the reservoir, clay is predominant $(68 \%)$.

Considering the above information, and the affinity of heavy metals for small particles, one might expect very low values of all metals at location 5 (the reservoir), which in fact was not the case. These results emphasize the necessity for an increased degree of examination of the species of metal present, which, together with knowledge of the sediment particle size classes, should permit a greater understanding of the processes influencing metal concentrations in the sediments.

The sampling points considered critical for metal analysis were the Sarandi and Ressaca streams. Within the industrial complex of Contagem, point 2 (Sarandi) receives a great part of the effluents from iron and steel industries (chromium, nickel, and copper residues), civil conctruction (cement), solvents and paints (oxides of nickel and chromium, used as pigments). According to Feam, 10 of the 30 industries located in this industrial complex, as well as one other nearby, can be considered as principally responsible for the emission of pollutants to this watershed. The high concentrations of metals at point 3 (Ressaca Stream) may be related to the polluting action of liquid wastes from land-fill dumps. The elevated concentrations recorded during the wet season might be related to point sources of industrial effluents, the land-fill dump of the city, and rain drainage.

The results of the present study emphasize the necessity for continued monitoring of heavy metals in this watershed, as part of the efforts to improve the water quality of the reservoir.

Acknowledgments - The authors are grateful to: the Department of Hydraulics and Sanitation of the São Carlos School of Engineering, University of São Paulo, for the use of the atomic absorption spectrophotometer; Júlio Cesar Trofino, technician of the Sanitation Laboratory of the latter department, for the heavy metal analysis; biologist Luíz Antônio Rocha, for invaluable assistance in the field; and Kennedy Roche (UFMS), for linguistic assistance. 


\section{REFERENCES}

AMERICAN PUBLIC HEALTH ASSOCIATION - APHA, 1995, American Water Works Association, Water Pollution Control Federation - Standard Methods for the Examination of Water and Wastewater. 19 $9^{\text {th }}$ ed., New York.

BARBOSA, F., GARCIA, F. C., MARQUES, M. M. G. S. M \& NASCIMENTO, F. A., 1998, Nitrogen and phosphorus balance in a eutrophic reservoir in Minas Gerais: a first approach. Rev. Brasil. Biol., 58(2): 233239.

BOLDRINI, C. V. \& PEREIRA, D. N., 1987, Heavy metals in Santos Bay and the Santos and São Vicente estuaries: bioaccumulation. Ambiente, 1(3): 118-127 (in portuguese).

BURGE, I. J. \& HUG, S. J., 1998, Influence of organic ligands on chromium (VI) reduction by Iron (II). Environ. Sci. Technol., 32: 2092-2099.

CHAMPS, J. R. B., 1992, Some considerations on the Pampulha watershed situation. In: H. P. Godinho (coord.), Anais do Seminário da Bacia da Pampulha. Editora SEGRAC, Belo Horizonte, MG, 204p. (in portuguese).

CONSELHO NACIONAL DO MEIO AMBIENTE CONAMA, 1986, Resolution n. 20, 10 June (in portuguese).

DEMAYO, A., TAYLOR, M. C., TAYLOR, K. W. \& HODSON, P. V., 1982, Toxic effects of lead and lead compounds on human health, aquatic life, wildlife plants and livestock. pp. 257-305. In: Guidelines for surface water quality. Vol. I, Inorganic Chemical Substances.

EYSINK, G. G. J., PÁDUA, H. B., PIVA-BERTOLETTI, S. A. E., MARTINS, M. C. \& PEREIRA, D. N., 1988, Heavy metals in the Ribeira Valley and Iguape, Cananéia. Ambiente, 2(1): 6-13 (in portuguese).

FREEDMAN, B., 1995, Environmental ecology: the effects of pollution, disturbance and other stresses. $2^{\text {nd }}$ ed., Academic Press, London.

GIANI, A., 1994, Limnology in Pampulha Reservoir: some general observations with emphasis on the phytoplankton community. In: R. M. Pinto-Coelho, A Giani \& E. Von Sperling (eds.), Ecology and human impact on lakes and reservoirs in Minas Gerais with special reference to future development and management strategies. Segrac, Belo Horizonte, MG, 193p.

JACKSON, J., 1992, Heavy metals and other inorganic toxic substances. pp. 65-80. In: S. Matsui (ed.), Toxic Substances Management in Lakes and Reservoirs, Guidelines of Lake Management. International Lake Environment Committee, Foundation \& United Nations Environment Programme, 169p.
LAURÉN, D. J. \& MCDONALD, D. G., 1986, Influence of water hardness, $\mathrm{pH}$, and alkalinity on the mechanisms of copper toxicity in juvenile rainbow trout, Salmo gairdneri. Can. J. Fish. Aquat. Sci., 43: 1488-1496.

MURRAY, K. S., CAUVET, D., LYBEER, M. \& THOMAS, J. C., 1999, Particle size and chemical control of heavy metals in bed sediment from the Rouge River, southeast Michigan. Environ. Sci. Technol., 33: 987-992.

ODUM, E., 1985, Ecologia. Editora Interamericana, Rio de Janeiro, 434p.

PAIN, D. J., 1995, Lead in the Environment, pp. 356-391, In: D. J. Hoffman, G. A. Rattner, A. Burton Jr. \& J. Cairns Jr. (eds.), Handbook of Ecotoxicology. Lewis Publishers, Boca Raton, Florida.

PINTO-COELHO, R. M., 1992, Evolution in the degree of eutrophication in Pampulha Reservoir: comparison of the seasonal cycles of nutrients ( $\mathrm{N}$ and $\mathrm{P}$ ) and planktonic organisms. In: H. P. Godinho (coord.), Anais do Seminário da Bacia da Pampulha. Editora Segrac, Belo Horizonte, MG, 204p. (in portuguese).

PINTO-COELHO, R. M., 1997, Cited on July 8, 1999, http://www.icb.ufmg.br/Pamp2.htm.

PINTO-COELHO, R. M. \& GRECO, M. K., 1998, Heavy metal concentrations in zooplankton and the macrophyte Eichhornia crassipes in the reservoir of Pampulha, Belo Horizonte, MG. Ciência e Tecnologia, Revista Técnica e Informativa da CPRM, ano VI, 10: 64-69 (in portuguese).

RIPLEY, E. A., REDMANN, R. E. \& CROWDER, A. A., 1996, Environmental effects of mining. St. Lucie Press, Delray Beach, Florida.

RIETZLER, A. C., LOPES, G. \& FONSECA, A. L., On the sediment characterization of Pampulha watershed, Minas Gerais, Brazil (in preparation).

UNITED STATES ENVIRONMENTAL PROTECTION AGENCY - USEPA, 1985, Ambient Water Quality Criteria for Lead, 1984. U. S. Environmental Protection Agency, Rep. 440/5-84-027, Washington.

WREN, C. D., HARRIS, S. \& HARTTRUP, N., 1995, Ecotoxicology of Mercury and Cadmium. pp. 392423. In: D. J. Hoffman, G. A. Rattner, A. Burton Jr. \& J. Cairns Jr. (eds.), Handbook of Ecotoxicology. Lewis Publishers, Boca Raton, Florida. 